\section{The Rôle of Feet in the Struggle for Existence}

MAY not the "set " of the feet in various races of men have played a not unimportant part in the struggle for existence? In thinking over the subject the following points have occurred to me, and perhaps some of your readers may be able to throw some further light on the question.

In the case of the North American Indian, for example, except that he wears soft mocassins instead of stiff boots, he is less in a state of nature as regards his feet than we are For we, and all the Teutonic tribes for countless generations, have paid little regard to our feet except as instruments of unconscious progression or as pedestals on which to stand firm. The North American Indian, on the contrary, is obliged by his habits of life, and has been obliged for hundreds, perhaps thousands of years, to direct his particular attention in no small degree to the position of his feet. For in hunting it is of the greatest importance that he shall not tread on any rotten stick which may snap with a loud noise and alarm the game of which he is in pursuit. On the war track' it is of equal importance that he shall deceive his enemies as to the number of his party, and so each man carefully steps in the footprint of the warrior who had preceded him. This, I should think, would

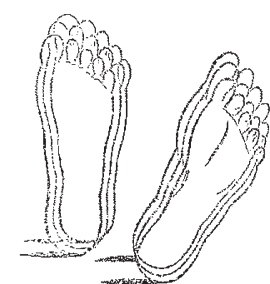
be decidedly easier if the foot were kept pointing straight fore and aft than if it were held obliquely. This may be more evilent from the three rough outlines I have drawn of footprints in each position, in which I have made the difference in the length of the stride much the same. Indeed, the difference is greater in the fore and aft one, and yet the impression made by the timree footprints will not be so large as when the foot is oblique. In walking in snow-shoes, too, the feet must be held as nearly as possible parallel, as otherwise the shoes are apt to catch in each other and trip their wearer up. It seems quite possible that long. continued attention to the position of the feet for many generations, together with the advantage which a parallel position of the feet may have conferred in the struggle for existence, may have led to its becoming a permanent characteristic of the Red Indian; while the advantage which the outward direction of the feet may have given the old Saxon, by affording a firmer support in a hand-to-hand struggle, may have led to its permanence in the successors of those who possessed this peculiarity, and by its means enabled them to overcome their opponents.

I cannot be quite sure about the ancient Egyptians. If I remember rightly, the Farnese Irercules has toes pointing considerabiy outwards, while Mercury generally has his feet more or less parallel. This would indicate that the Greeks associated the former position with strength and firmness, and the latter with fleetness. As fleetness will also aid the North American Indian in the struggle for existence, it is possible that its association with a parallel foot may have something to do with the peculiar formation of his ankle-joint. This, however, leads us to the question which I do not think has ever yet been taken up: In what way does the possession of a certain kind of weapon and the use of particular methods of warfare infuence the conformation of the body? Have the descendants of the Teuton tribes toes which point outwards because their forefathers used clubs, axes, and targets, and have the Red Indians of the present day parallel feet because their forefathers used arrows and lieen tomahawks, and trusted to agility rather than to brazen studs and thick bull-hide for escape from the blows of their adversaries?

X.

\section{Destruction of Flowers by Birds}

A VELL-OBSERVED case of the destruction of primrose flowers by birds will perhaps be of interest to some of your readers.

The flowers of two plants of primrose at a short distance from a window have during the last tew days been almost entirely destroyed; and this having drawn attention to the subject, they have been watched. The result is that a number of the common house-sparrows have been seen to peck off the flowers by cutting them through at the base of the tube of the corolla, so as to remove the oyarium. In some cases the flower has not been completely detached from its stalk, a ragged hole being left where the ovarium originally was placed, but the flower has never been subject to any further dismemberment. The few flowers which have been left on the plants, when chewed in the mouth, do not seem to have any sweetness about them, and one would therefore suppose that they do not contain any appreciable quantity of nectar.

The inference from these observations seems to be that the sole object of the destruction of the flowers is to obtain the ovaria. It is also to be observed that the primrose is not indigenous to this part of the country, and the only plants within a radius of at least two miles are those cultivated in gardens. The cowslip is, however, very abundant, but I have never noticed any similar destruction of it. I shall, now the cowslips are coming into flower, watch them with, the object of finding out whether they are attacked or not.

\section{H. GEORGE FORDHAM}

\section{Note on the Common Sole}

IN looking over Mr. Buckland's last work on "British Fishes," I did not find any account of the power the Sole has of fixing itself against the glass of an aquarium by means of a sucker placed close to the mouth, on the lower side; and as I find it is one of the "things not generally known," I think it may be worth your notice, particularly as I have not remarked it at the Brighton Aquarium. I first observed the fact at the Havre Aquarium, where I pointed it out to many persons hitherto unacquainted with it, but $I$ have been disappointed at not seeing it at Brighton duing any of my visits. The only way $I$ can account for this difference in the habits of the same fish is that the Brighton Soles being, auring my visits, always in the light, lay quietly at the bottom, whereas those at Havre, being almost excluded from the light, were seen to much greater advantage, swimming about freely and attaching themselves to the glass when they came in contact with it, or sliding down to the ground. The sucker of a Sole nine inches long would be about $\frac{3}{4}$ inch by $\frac{1}{2}$ inch, placed diagonally to the long dianeter of the fish, and exhibiting fine radiating lines. Though I watched other flat-fish carefully, I never could detect any attempt in them to fix themselves against the glass when they struck it, and therefore I am quite unable to explain why the Sole alone should have this power. As I make no pretension to be an ichthyologist, it is very probable that I may be telling a thrice-told tale. I must therefore leave it to your judgment to decide whether it is worth your notice in NATURE.

Eastboume

T. OGIER WARD

\section{Colour in Goldfinches}

LAST July I took a goldfinch's (Cardubelis elegans) nest with five young birds in it out of a tree in my garden and brought them up. Four tumed out to be properly marked specimens, but the fifth is almost black, only having a few red feathers on its head. I see in Bechstein's "Cage Birds" (third edition), p. I47, that "four young ones of this variety were found in the same nest." Now, why were not all my five specimens black, and what is the cause of the fifth's blackness? Can any of your readers say?

$$
\text { Manley, May } x
$$
LUCIE WOODRUFEE

\section{OUR ASTRONOMICAL COLUMN}

VARIABLE STARS.-The two following stars require further examination, as affording signs of fluctuating brightness. (1) Lalande $23228-9$, estimated 7 th magnitude, 1795 May 8 , and $5 \frac{1}{2}$, 1798 March 14 . It is 67 in Lamont (No. I149), and in Steinheil's Chart, one of the series published by the Berlin Academy, it is only 8 th mag. Neither Bessel nox Santini has observed it. (2) The star Lalande 27095 , in Boötes, 7 th mag., observed I795 May 25, and missed by Olbers, 1804 March 22, during his observations of the comet of that year : it is the star which passed the centre wire at $14 \mathrm{~h}$. $42 \mathrm{~m}$. Ios. (Histoire Céleste, p. 164), and Olbers distinctly says of it "ist nicht mehr am Himmel zu finden." It was, however, observed by Bessel in his Zone 4I5, 1828 May 24, as a 9 th magnitude; it is 9 " in the "Durchmusterung," and is called $9^{\circ} x, 1866$ June 5 , in the Bonn Observations, vol. vi. The positions of these stars for $1875^{\circ} \circ$ are :-

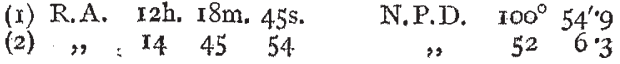

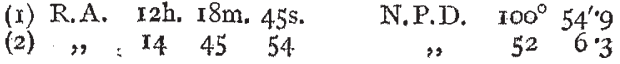


The BINARY STAR $\Sigma 2107 .-$ This undoubted binary, first measured by Struve in the year 1828 , well merits attention, and it may soon be possible to gain an idea of the form of the orbit. The recent measures of Dembowski and Barclay prove the angular velocity to be still increasing, the accompanying diminution of distance requiring pretty large telescopes to be brought into requisition for satisfactory observations. Dembowski calls ә principal component a 7 th magnitude, bright yellow; the smaller one a 9 th and dusky. This star is Herculis 197 (Bode), and its place for $1875^{\circ} \circ$ is in R.A., $16 \mathrm{~h} .46 \mathrm{~m} .54 \mathrm{~s}$. ; N.P.D., $6 \mathrm{I}^{\circ} 7^{\prime}$.

High-Latitude Phenomena. - Our correspondent "H. F. C." who writes from San Francisco, California, with regard to a statement in the recently-published narrative of the "German Arctic Expedition," that "the moon shone without setting for several days" in November, refers to a phenomenon which must necessarily occur in circumpolar latitudes. As an illustration : In lat. $82^{\circ} \mathrm{N}$. and long. $60^{\circ} \mathrm{W}$., near which position a part of the expedition about to leave our shores is expected to winter, the moon in December next will rise on the 8th, and will not set until the I 8 th, attairing her greatest altitude above the horizon at meridian passage on the 13 th. The sun during this interval is, of course, invisible in lat. $82^{\circ} \mathrm{N}$., but there is continuous moonlight for between nine and ten days, and similarly for other months during the Arctic winter.

The SOLAR EClipse, I876, March 25.-This eclipse will be a very similar one to that of March 1858 , which created so much interest in its passage across this country: it will be annular, but in those parts of the track of central line, where the augmentation of the moon's geocentric semi-diameter is greatest, the eclipse, though still annular (as in England in I 858), approaches very near a total one. Vancouver Island is situate in this track, which runs about centrally over it, as the following points will show :-

$\begin{array}{ccc}\text { Longitude } & 127^{\circ} & 6^{\prime} \mathrm{W} . \\ " & 126 & 4 \\ " & 125 & 5 \mathrm{I} \\ " & 125 & 15 \\ " & 122 & 46\end{array}$

$\begin{array}{ccc}\text { Latitude, } & 48^{\circ} & 42^{\prime} \mathrm{N} \\ " & 49 & 30 \\ " & 49 & 40 \\ " & 50 & 6 \\ " & 5 \mathrm{I} & 50\end{array}$

A direct calculation for the third of the above points, in Vancouver Island, gives for the duration of the annulus only 7.5 seconds, the middle at oh. $25 \mathrm{~m}$. 29s. local mean time with the sun at an altitude of $44^{\circ}$ : the apparent semi-diameter of the moon is $I^{\prime \prime} 5$ less than that of the sun. The central line subsequently traverses the Lesser Slave Lake and Lake Athabasca, with slightly longer duration of annulus. The eclipse will be visible in its partial phase in the position of the winter quarters at which the British Arctic Expedition aims.

The Minor Planet "Lydia."-M. Leverrier's Bul. letin International of April 29 contained a telegraphic notice of the discovery of a supposed new member of the minor planet group, at the Observatory of Toulouse, by M. Perrotin, on the same morning, which in the following Bulletin is recognised as No. Iro, Lydia, detected by M. Borrelly at Marseilles on April 19, 1870; the ephemeris (Berliner Fahrbuch) being much in error. The elements of No. IIo, calculated by Dr. Oppenheim of Königsberg, and brought up with perturbations to 1874 (Astron. Nach., No. I,971), give a position for April 28, differing considerably from that assigned by the observation at Toulouse; but if we apply a correction to the mean anomaly of $+I^{\circ} 2 I^{\prime} 57^{\prime \prime}$, the observed and computed longitudes agree, and the latitudes differ only one minute, and the diurnal motions also accord, so that there can be little doubt that the identification of M. Perrotin's object with No. I xo is correct. With the above correction the mean anomaly, April 28.5 Greenwich mean time, is $262^{\circ} 8^{\prime} 27^{\prime \prime}$, and thus with the other elements given by Dr. Oppenheim we have the following positions, which will be pretty near the true ones. At $12 \mathrm{~h}$. Greenwich mean time :-

\begin{tabular}{|c|c|c|c|c|c|c|c|c|c|c|}
\hline & & & & $\begin{array}{l}\text { R.A. } \\
\text { m. }\end{array}$ & & & & P.D. & & g. distance. \\
\hline May & 3 & $\ldots$ & 15 & & 17 & $\ldots$ & 105 & 29.5 & $\ldots$ & $0 \cdot 2498$ \\
\hline " & 5 & $\ldots$ & & 2 & 27 & $\ldots$ & ", & $25 \cdot 8$ & $\ldots$ & \\
\hline & 7 & $\cdots$ & I5 & o & $3^{6}$ & $\cdots$ & ", & $22 \cdot 2$ & $\ldots$ & $0.248 \mathrm{I}$ \\
\hline , & 9 & $\ldots$ & I4 & $5^{8}$ & 45 & $\ldots$ & ", & 18.5 & $\ldots$ & \\
\hline & I I & $\ldots$ & ", & $5^{6}$ & 54 & $\ldots$ & ", & 14.9 & $\ldots$ & 0.2476 \\
\hline , & I3 & $\ldots$ & ", & 55 & 4 & $\ldots$ & , & I $\mathbf{I} \cdot 3$ & $\ldots$ & \\
\hline$"$ & 15 & $\ldots$ & ", & 53 & I5 & $\ldots$ &, & 7.8 & $\ldots$ & 0.2482 \\
\hline & 17 & $\ldots$ & ," & $5^{I}$ & 28 & $\cdots$ & ," & 44 & $\ldots$ & \\
\hline & 19 & $\ldots$ & 14 & 49 & 42 & $\ldots$ & 105 & $1 \cdot 2$ & $\ldots$ & $0: 2499$ \\
\hline
\end{tabular}

\section{LECTURES AT THE ZOOLOGICAL GARDENS* \\ Mr. F. W. Clarke on Sea Lions and Seals}

II.

THE Sea Lion that is best known is the Northern Sea

Bear (O. ursina), which is almost entirely confined to the Pribylov Islands. These islands were discovered in 1787 by a Russian sailor of that name. The slaughter of the animals is under the regulations of the United States Government. There are two islands, that of St. Paul and that of St. George, and the number of seals that have been calculated to exist in a given year upon one of them-namely, $1,152,000-$ will give a good notion of the multitudes of these animals to be met with at one of their favourite haunts. There is about half that number on St. George, making nearly $2,000,000$ on the two islands. Out of this vast number, 100,000 are annually killed, principally young males. In South Shetland the "take" of fur seals was 320,000 in 1821 and 1822 , and as all that arrived were killed, the speedy extinction of the colony was the result. The same happened in New Zealand.

A full-grown male Otaria ursina is between seven and eight feet long, the female not being more than four feet. The males reach their maximum size at about the sixth year, the females at the fourth. The hairy coat consists of an outer covering of long, flattened, coarse hair, beneath which is a dense coating of long, fine, silky fur.

The next species is Steller's Sea Lion (O. stelleri), named in honour of its discoverer. It is much larger than the other species, the males being as much as sixteen feet long. The ears are short and pointed, much broader than those of the Fur Seal. It is found on the island of St. Paul, extending down the coasts of Kamschatka and California. At San Francisco it inhabits an island in the harbour where Mr. Woodford has built a large hotel, to which parties resort to dine and look at the Sea Lions play. The under-fur of this species is so short as to be useless for clothing purposes.

There is another Otaria on the Californian coast, found in Japan also. It was first described by Schlegel from specimens collected by Siebold. It has been named O. gilliespii, but it would be far better to adopt the name since suggested by its original describer, and call it O. japonica. It is much smaller than the species named after Steller, and the skull presents an exceptionally large crest.

The next species to be mentioned is the one which extends round South America, from Peru to the River Plate-Otaria jubata-of which a specimen is living in the Garclens, having been obtained by its keeper, François Lecomte, from the Falkland Islands, when a mere pup. A full-grown male may reach nine feet in length, the females being much smaller. The fur is of no use for sealskin, as the undercoat is very scanty. The male has a mane, and is therefore called "Lion."

Inhabiting precisely the same localities, round Cape Horn and the Falkland Islands, is the Fur Seal of com. merce-Otaria falklandica. It is much smaller than the

\footnotetext{
* Continued from vol, xi, p. 5r4.
} 